Nader Mohammad Aljawarneh,

Jadara University, Jordan

(iD) ORCID ID 0000-0001-5707-8253

email:n.jawarneh@jadara.edu.jo

Munsif Sokiyna,

Ph.D., Cyprus International University, Cyprus

(iD) ORCID ID 0000-0001-5177-7395

email:munsif.sokiyna@gmail.com

Abdallah Mishael Obeidat,

Jadara University, Jordan

(iD) ORCID ID 0000-0002-8008-1023

email: aabdullahh2000@hotmail.com

Khaled Abdel Kader Alomari,

Jadara University, Jordan

(iD) ORCID ID 0000-0003-3621-5540

email: omari@jadara.edu.jo

Ahmad Tawfig Alradaideh,

Jadara University, Jordan

ORCID ID 0000-0003-4531-8998

email: radaideh@jadara.edu.jo

Ziyad Saleh Alomari,

Jadara University, Jordan

ID ORCID ID 0000-0003-3634-5652

email: zeyado@jadara.edu.jo

Correspondence email: n.jawarneh@jadara.edu.jo

\title{
THE ROLE OF CRM FOG COMPUTING ON INNOVATION AND CUSTOMER SERVICE QUALITY: AN EMPIRICAL STUDY
}

Abstract. CRM fog computing and entrepreneurial, innovation and service quality has been identified as an important driving forces for job growth. The study aimed to identifying the involvement of CRM fog computing on entrepreneurial, innovation and service quality in the Jordanian telecom company. The authors employed a quantitative approach to identify the level of Appling of CRM fog computing in the company. The study contained the findings of questionnaire of 325 respondents (male and female employees). Multiple linear regression and One-Way ANOVA analyses were used to examine the data. The predictive model of CRM fog computing and entrepreneurial, innovation and senvice quality was significant impact. Implications for CRM fog computing and practice are entrepreneurial, innovation and service quality are discussed. The researchers recommend to build enthusiasm for creating fog CRM mist processing as a result of its job in client administrations improvement: to increase using the information provided by CRM system in decision making; to consider senvices quality more as it affects sales volume positively; to consider customer's feedback, listen to their opinions about the services provided to enhance performance. Entrepreneurship and innovation are increasingly an indispensable portion of organizations nationally, regionally and globally, and considered as powerful tool for revenue streams. The authors state that entrepreneurship uses innovation to expand business scope and boost growth. Therefore, entrepreneurship and innovation are dynamic and holistic processes that are not confined to the initial stage of a new venture. The implementation of CRM Fog computing and entrepreneurial aids the organisation's productivity because it enhances the product and services offered by several organizations that adopts it concept. It enhances services to customers due to its easy to access nature and as well. The authors conclude that CRM Fog computing improves the ecommerce of any organization or community that adopts its concept and applies it in all areas.

Keywords: CRM fog computing, entrepreneurial, innovation, service quality, customer experience.

Cite as: Alijawarneh, N. M., Sokiyna, M., Obeidat, A. M., Alomari, K. A. K., Alradaideh, A. T., \& Alomari, Z. S. (2020). The Role of CRM Fog Computing on Innovation and Customer Service Quality: an Empirical Study. Marketing and Management of Innovations, 2, 286-297. http://doi.org/10.21272/mmi.2020.2-21 
N. M., Aljawarneh, M., Sokiyna, A. M., Obeidat, K. A. K. Alomari, A. T., Alradaideh, Z. S., Alomari. The Role of CRM Fog Computing on Innovation and Customer Service Quality: an Empirical Study

Introduction. Increased competition and erosion of product differences between companies prompted the focus on companies to provide unique value to their customers (Soliman, 2011). The increased competition to gain customer satisfaction requires the company to focus on the essential skills in applying to improve the value of the customer (Vikkraman \& Duraikannan, 2015). CRM is crucial to achieving the quality of service and speed response to the changes in the market due to technological advancement, $E$ CRM is increasingly being used as a marketing model, as well as a strategy to enhance organisational flexibility (Mang'unyi et al., 2017). CRM Fog computing is a mixture of business and technology strategies that helps companies focus on the customer (Khlif \& Jallouli, 2014). CRM Fog computing is a necessary process for selecting the clients in which the company can earn money through them, access and customer interaction to maximise the present and future value of the company's customers (Kumar \& Reinartz, 2012). Thanks to customer identification, acquisition and retention, CRM Fog is the best commercial addition by managing and coordinate the client's interactions, as managing foggy relationships assists the companies in maximising the importance of each customer's communication and enhancing the company performance (Moorthi \& Nallampalli, 2020).

Entrepreneurship is a strong social and economic engine that leads to technological progress, economic growth and social mobility (Klepper, 2015). It is an essential driving force for job growth and the growth of individuals who create companies that are the principal source of economic outgrowth, especially in emerging economies. Therefore, promoting entrepreneurship is a vital policy pursued by many organisations (Su et al., 2020). The procedures of recognising and utilising potential business chances by reassembling existing resources or creating new resources to evolve the market services and new services (Hitt et al., 2001). The entrepreneurial approach mostly links with new job ideas that can cause some changes in the market and works to improve the company's capability. It provides technical knowledge, an enabling way to provide technical solutions to meet consumer requirements (Sulistyo \& Ayuni, 2020). Entrepreneurship could be characterised as an innovative process creative, play the potential role of the value of the production of new services, improve productivity, and bring new job opportunities, and market diversification, and promote social welfare, promoting economic level (Guerrero et al., 2008).

Innovation is the core of corporate prosperity, especially growing sales and organisational excellence throughout new products and services (Sulistyo \& Siyamtinah, 2016). Innovation is vital to the continuation and development of the companies. It creates new products in addition to new services that enable companies to obtain competitive advantages and achieve significant market returns (Aljawarneh \& Atan, 2018). Creativity needs to include multiple dimensions as a model (Appiah-Kubi \& Doku, 2010). that has adopted innovative behaviour oriented towards the development of customer-cantered, technologyfocused marketing-focused activities (Hogan \& Coote, 2014). Creativity stimulating creativity remains a challenge for most companies because innovation activities are inherently different from standard tasks such as manufacturing and marketing (Tian et al., 2014).

Quality is the major factors that affecting a customer's purchasing decisions and that the QoS increases customer satisfaction, and in turn, increases corporate profits (Jiang \& Zhang, 2016). QoS is considered a basis for improving customer's loyalty as the quality of service is determined at the time of providing the service, which means that it will be determined by service consumers and not the provider in the field of marketing, and this means that it is perceived quality (Kiran \& Diljit, 2017). The quality of service has been defined. It is the extent to which the service matches the requirements or expectations of the clients (Mitchell, 1990). QoS has been considered one of the issues most focused on by various industries, an important factor affecting whether the sector is sustainable (Parasuraman et al., 1985). Service is a crucial tool for the company's fight to differentiate itself from its rivals in the same market (Ladhari, 2008). Many organisations seek to develop and improve their relationship with their customers, as well as achieving growth and maintaining good competition in the company's position and achieving a 
N. M., Aljawarneh, M., Sokiyna, A. M., Obeidat, K. A. K. Alomari, A. T., Alradaideh, Z. S., Alomari. The Role of CRM Fog Computing on Innovation and Customer Service Quality: an Empirical Study

competitive advantage in performance. The importance of the customer, taking care of him and meeting his requirements has led to the companies 'concentration and adoption of modern technological systems, which would motivate customers to increase the demand for goods and services. In the end, it would lead to profit and reach the goals that companies seek to achieve.

Moreover, changes in customer service requirements, intense competition in market share and rapid growth in technology necessitated that companies create an effective system. Such a system should facilitate procedures an workflow, controls multiple processes, exchanges of data and information between different activities, and assists management in creating new services and products which were not available in the market. It allows maintaining a competitive advantage and ensuring its continuity, reducing costs and increasing efficiency in meeting customer requirements. Among these systems that can change the nature of customer service is CRM fog computing. Accordingly, this study came to indicate the role that fog computing CRM plays to improve customer service, increase creativity, and lead in the businesses that companies perform.

Literature Review. CRM Fog Computing, Entrepreneurial, Innovation \& Service Quality: CRM Fog account was a suggested idea to move loT departments (i.e. portability support, mindfulness, geopublishing and deceleration) from the edge of the system. By extending cloud data centre assets (shape, storage, and system assets) in the closest area to end customers, Fog Logging is likewise proposed to improve implementation of several applications that require deep sleep from loT tools to the nearest fog server, or applications that perform action information locally created (Mahafzah et al., 2020). CRM Fog computing is a mixture of technology and business procedures (Khlif \& Jallouli, 2014) that supports companies concentrate on the customer. CRM Fog computing is a strategic customer choice process in which a company can earn money, access, and customer interaction to increase the present and future value of the company's customers (Kumar \& Rents, 2012).

Quality of services is the difference among the level of real service performance and the level of expected return, that is, the quality of services is a measurement of the service suitability to customer requirements (Mahafaza et al., 2020; Malkawi et al., 2017). Services are progressively an irreplaceable bit of associations broadly, locally and all-inclusive, and considered a useful asset for income streams. In this way, the accomplishment of a service supplier frequently obviously depends on the elevated level of association with the customers which decides client steadfastness and fulfilment that QoS impacts the company's results, for example, expanding deals and benefit (Mori et al., 2013), improving client relations, execution predominance, piece of the overall industry (Poretla and Thanassoulis, 2005), enhances unwavering client ness and corporate picture (Newman, 2001). In which, consumer loyalty and QoS have identified with steadfastness the conduct of client using repurchase aims (Kheng, 2002), and along these lines' conveyance of higher calibre of service to patients/clients is unavoidable for endurance and achievement of the emergency clinics in the present dynamic and severe condition.

The term innovation refers to working to find something new, as achieving it is a unique resource for the company. In contrast, change is the integration of these new resources and their marketing well (Alcouffe, 2004). Projects can only develop in an environment where there are an entrepreneurial spirit and a love for creative work, which led to a group of businessmen with managerial talents such as preparing for risk, adopting new ideas, and understanding the mechanisms of competition in the market. Creativity is considered as all further or all small or significant improvement in products and production methods. It takes place through an individual or collective effort. It proves its success from a technical or technological point of view as well as its economic effect. It is the process that allows the organisation to achieve a high degree of coordination and cooperation between its activities. Various as production, marketing, research and development, to adopt unique ideas and methods and implement them in the field of work to add a new service or create a production process, as well as to make the organisation the best in the competition market (Al-Da'abseh et al., 2018). 
N. M., Aljawarneh, M., Sokiyna, A. M., Obeidat, K. A. K. Alomari, A. T., Alradaideh, Z. S., Alomari. The Role of CRM Fog Computing on Innovation and Customer Service Quality: an Empirical Study

Entrepreneurship is considered as a set of characteristics and types of behaviour related to choosing a business or work, planning it, organising it and taking its risks and creativity in managing it. It is also an initiative or movement process and with high risk, which includes a combination of capital, technology and human skill, and it is applicable in all businesses regardless of About its size and economic or service orientation. Therefore, entrepreneurship is one of the essential and promising fields in the economies of advanced industrial countries and developing countries. The entrepreneurship contributes an active contribution to economic development. It is considered a fundamental concept to focus on creativity and leadership as it has technological dimensions, a new product, or a new way to present the service. Accordingly, entrepreneurship depends on diversification, differentiation and the introduction of new methods, as the entrepreneur is the person who possesses institutional building skills as well as administrative and creative skills that help him in building organisation or management of the institution (Bygstad \& Presthus, 2012).

CRM Fog, Computing \& Entrepreneurial. Entrepreneurship can assume a significant job in the financial advancement of a nation (Coviello and Munro, 1995; Antoncic et al., 2000; Knight and Cavusgil, 1996; Busenitz et al., 2000; Bosma, 2010; Irtaimeh et al.,2016). The writing recognised two expansive kinds of entrepreneurship. Opportunity entrepreneurship alludes to beginning a business to misuse an apparent unexploited or under-abused business opportunity, i.e., the intentional idea of cooperation in entrepreneurship. Need entrepreneurship, then again, alludes to beginning a business as the best choice accessible for work yet not the favoured choice (Antoncic \& Hisrich, 2000; Abualoush et a., 2018). Besides, new firm creation has been recognised as a fundamental factor in driving the financial development of a nation and producing work openings (Aljawarneh \& Al-Omari). CRM Fog processing helps associations to separate client fragments dependent on productivity and business separated from distinguishing the related dangers with credit customers. Clients are generally similar to leave banks and reacting to other accessible ideas from contenders (Ahmad et al., 2019). As indicated by Aljawarneh \& Al-Omari (2018) CRM Fog figuring assumes a considerable job in the financial business by supporting banks to catch the client's information and to upgrade the openness of client data, so it empowers bank offices to improve their corporate personality. Wang et al., 2019 in their examination, they inspected the viability of CRM Fog registering in the commercial segment, just as the relationship of CRM and innovation direction, dependability, process-driven methodology, client experience, and official duty. These last factors were viewed as the significant develops of CRM Fog figuring adequacy. From the discoveries, unwavering quality, process-driven methodologies, and authoritative responsibility were recognised as three develops of CRM Fog figuring viability with a positive impact on consumer loyalty; while dependability positively affected both client steadfastness and fulfilment. CRM Fog Computing \& Innovation. CRM Fog processing is an idea received by associations through online to deal with the connections of an association with its clients, clients and all the issues identified with deals and budgetary exchanges. It is the innovation right now to oversee and encourage the association's business procedures and exercises regularly. Accordingly, CRM Fog figuring is viewed as a key business and procedure (Al-Omari, et al., 2018; AlOmari, et al., 2020; Al-Da'abseh, et al., 2018). Also, there is a need to perceive that CRM Fog registering has a long-haul point which is to improve the quality and to upgrade the interface with the clients which result in consumer loyalty (Tao et al., 2011). It's strongly suggested and required the top administration framework duty and vision for a fruitful CRM Fog figuring execution. Structure of the approaches system should be adaptable and straightforward, particularly the evaluating strategies. These angles are key issues to redesign the clients' fulfilment and the advantages of the firm (Khaligh et al., 2012). Assessment of the innovation writing affirms that there is a huge decent variety in perspectives and ways to deal with what establishes inventive movement. It features a portion of the disarray that exists inside the train itself. The disarray appears to come from the way that numerous definitions present fringe ideas, which may divert consideration from the centre parts of innovation and make its application troublesome. Numerous 
N. M., Aljawarneh, M., Sokiyna, A. M., Obeidat, K. A. K. Alomari, A. T., Alradaideh, Z. S., Alomari. The Role of CRM Fog Computing on Innovation and Customer Service Quality: an Empirical Study

definitions have been proposed to clarify innovation, and therefore, the term has increased more noteworthy uncertainty (Garcia and Calantone, 2002).

CRM Fog, Computing \& Service Quality. IT organisations must discover methods that can make them provide creative business services while cutting the organisation's expenses out of its activities to make their company reliable in today's complicated market environment (Alshare et al., 2020). It is not just a successful economic model correctly applied for operating expenses to be reduced and maintain IT infrastructure. Research has indicated that the cost of deploying 1000 traditional servers can be saved by 50 to $67 \%$ in cloud computing (Bibi et al. 2014). Many companies also use cloud computing because it is essential in performance growth and its effect on businesses' output (Mohammed, 2012). CRM Fog computing is an activity where a massive number of heterogeneous worldwide and decentralised devices communicate and potentially cooperate among themselves. The network carries out storage and processing tasks without the intension of third parties which enables and makes data processing quicker, better and more productive (Aljawarneh \& Al-Omari, 2018). There is a significant relationship among CRM Fog computing responding and time because it Consortium as; «a system-level horizontal architecture that distributes resources and services of computing, storage, control and networking anywhere along the continuum from Cloud to Things». (Atlam, Walters \& Wills, 2018). Various sensors and another datasensation technology, an exponentially increasing amount of data are being captured in business workouts due to the evolution of the loT. (Mahafzah et al., 2020).

The development of CRM Fog processing was because of critical technique to distinguish the banks' beneficial clients and possibilities. It too empowers associations to devote time and consideration regarding improving the associations with their customers through them redid administrations, reestimating, optional dynamic, and advertising (Vella et al., 2012; Awasthi and Sangle, 2013; Farquad et al., 2012; Aljawarneh \& Atan, 2018; Alshare et al., 2020).

After the literature review, this study tested the following hypotheses:

$\mathrm{H} 01$ : There is a significant connection between CRM fog computing and entrepreneurial.

$\mathrm{H} 02$ : There is a significant connection between CRM fog computing and innovation.

H03: There is a significant connection between CRM fog computing and service quality.

Methodology and research methods. This study develops a series of questions concerning the role of CRM fog computing for enhancing entrepreneurial, innovation and service quality. The research follows a line of the deductive system to align these specific criteria in a pilot study, and a set of evaluation methods aimed at assessing the competitiveness of CRM fog computing on entrepreneurship, innovation and quality of service. This study has to do with quantitative analysis. Quantitative research defines what it is. Analytical research determines the way of how it becomes (Ethridge, 2004). In this paper, a quantitative approach is used to define the role of CRM fog computing in quality of service, entrepreneurship, and innovation. Furthermore, primary data were collected from the respondents using the questionnaire instrument. After data collection and analysis, the results were presented; Conclusions and recommendations were given. The number of study personnel reached 578 employees listed in the main branches of Jordan Telecom in Jordan. The study includes 325 employees from IT, HR, Marketing and Management divisions. The authors analysed collected data using the SPSSv19. This program fits with its quantitative approach (al-Bourne et al., 2020). Sekaran \& Bougie, (2015) this is the process of discovering that the elements in the research instrument lead to collecting accumulated data. Emphasis is placed on ensuring that each dimension is accurately represented through its features suitably and that the details measure their sizes. The researcher used deputies above $30 \%$ at the level of importance (AlJawarneh \& Al-Omari, 2018). Table 1 represents a statistically significant relationship among the elements of the variable that indicates the validity of the structure of the ingredients. With the chief remark on the reactions of the investigation test on the things the factor examination was applied, for every factor, the stacking and communalities estimations of each factor were determined. 
N. M., Aljawarneh, M., Sokiyna, A. M., Obeidat, K. A. K. Alomari, A. T., Alradaideh, Z. S., Alomari. The Role of CRM Fog Computing on Innovation and Customer Service Quality: an Empirical Study

Table 1. Pearson correlation coefficients

\begin{tabular}{cccc}
\hline Elements & Items & Relationship & Significant \\
\hline CRM fog computing & 15 & 0.801 & 0.000 \\
Entrepreneurial & 4 & 0.799 & 0.000 \\
Innovation & 5 & 0.864 & 0.000 \\
Service quality & 4 & 0.779 & 0.000 \\
\hline
\end{tabular}

Source: developed by the authors.

Table 2 uncovered that all loadings and commonalities for all elements were high and called attention to that the vast majority of real asset acknowledged these outcomes on the off chance that they were higher than 0.35 (Sekaran and Bougie, 2014).

Table 2. Represents the value of loadings and communalities

\begin{tabular}{cccccccccccc}
\hline \multicolumn{4}{c}{ CRM fog computing, \% of Variance: $(\mathbf{3 8 . 6 6 \% )}$} & \multicolumn{5}{c}{ Entrepreneurial, Innovation \& Service quality, \%of } \\
Variance: (43.15\%) \\
\hline No. & Load & Com & No. & Load & Com & No. & Load & Com & No. & Load & Com \\
1 & 0.758 & 0.435 & 9 & 0.650 & 0.630 & 16 & 0.647 & 0.645 & 24 & 0.645 & 0.647 \\
2 & 0.623 & 0.643 & 10 & 0.559 & 0.472 & 17 & 0.758 & 0.756 & 25 & 0.655 & 0.536 \\
3 & 0.461 & 0.552 & 11 & 0.467 & 0.480 & 18 & 0.862 & 0.762 & 26 & 0.467 & 0.441 \\
4 & 0.442 & 0.465 & 12 & 0.679 & 0.594 & 19 & 0.742 & 0.770 & 27 & 0.684 & 0.657 \\
5 & 0.627 & 0.474 & 13 & 0.689 & 0.680 & 20 & 0.475 & 0.481 & 28 & 0.669 & 0.567 \\
6 & 0.724 & 0.482 & 14 & 0.475 & 0.476 & 21 & 0.491 & 0.448 & & & \\
7 & 0.762 & 0.666 & 15 & 0.454 & 0.360 & 22 & 0.663 & 0.662 & & \\
8 & 0.533 & 0.41 & & & & 23 & 0.530 & 0.471 & & \\
\hline
\end{tabular}

Source: developed by the authors.

The researcher used Cronbach alpha to assure the consistency of the survey items. According to (Sekaran \& Bougie, 2014), the acceptable value is $70 \%$ and above. The result shows that correlation values were high and above 0.70 . It leads to accepting the reliability of the instrument in the authors' investigation. Table 3 shows that percentage of males represented was 214 while the rate of female described was 111. And the highest percentage of the sample was 301 was for holders of a Bachelor degree and the second-ranked for a master's degree holders represented. However, the lowest rate of $\mathrm{PhD}$, which was 8 of the total study sample. So, the results indicate that most respondents are mature enough to reduce Role of CRM fog computing on entrepreneurial, innovation \& service quality at Jordanian Telecom Company in Jordan.

Table 3. Demographical characteristics of the respondents

\begin{tabular}{cccc}
\hline Categories & Frequency & Categories & Frequency \\
\hline Gender & & From 5<10 years & 77 \\
Meal & 214 & From 10<15 year & 135 \\
Female & 111 & From 16< 20 year & 44 \\
Qualification & & 20 years or more & 32 \\
Bachelor & 301 & Job description & 98 \\
Master & 16 & Management & 50 \\
Doctorate & 8 & Marketing & 100 \\
Experience & & HR & 77 \\
<5 years & 37 & IT & 327 \\
\hline
\end{tabular}

Source: developed by the authors.

Results. 4th employee's M fog computing showed the means and standard of CRM fog computing as seen by employees. 
N. M., Aljawarneh, M., Sokiyna, A. M., Obeidat, K. A. K. Alomari, A. T., Alradaideh, Z. S., Alomari. The Role of CRM Fog Computing on Innovation and Customer Service Quality: an Empirical Study

Table 4. Represents The attitudes about CRM fog computing

\begin{tabular}{ccc}
\hline Fog CRM is easy to learn. & M & SD \\
\hline CRM fog computing is characterised in high reliability. & 4.21 & 0.76 \\
This company delivers services at the earliest. & 4.25 & 0.77 \\
CRM fog computing has efficiency in character. & 4.20 & 0.80 \\
Training that I received contributes to enhancing my usage of CRM fog computing. & 4.21 & 0.80 \\
CRM fog computing gives accuracy in the essential input and output data. & 4.13 & 0.81 \\
CRM fog computing consistently provides information. & 4.13 & 0.86 \\
CRM fog computing provides decision-makers with accurate information & 4.13 & 0.87 \\
CRM fog computing is characterised in high reliability. & 4.14 & 0.78 \\
CRM fog computing provides an interface suitable for use. & 4.11 & 0.71 \\
CRM fog computing provides information at the required time. & 4.21 & 0.83 \\
CRM fog computing characterised by flexibility in use. & 4.23 & 0.82 \\
Characterised information provided by the CRM fog computing in clarity. & 4.12 & 0.81 \\
Characterised information provided by the CRM fog computing in the comprehensiveness. & 3.92 & 0.83 \\
Department of Information technology of the company provides appropriate solutions to the problems & 3.92 & 0.81 \\
facing the user CRM fog computing. & 3.90 & 0.86 \\
General tendency & 4.11 & 0.45 \\
\hline
\end{tabular}

Source: developed by the authors.

Table 4 shows that the attitudes of the participants in the research sample were very high towards all the elements related to CRM fog computing that ranged between 3.91-4.25; A review of the order of the parts shows that the component was 12. Generally, the overall results indicated a high level of CRM fog computing, and the mean was $4.11, S D=0.45$, showing similarities in situations with no variation among respondents in the study regarding this variable.

Table 5. Attitudes regarding entrepreneurial, innovation \& service quality

\begin{tabular}{|c|c|c|c|}
\hline No. & Items & M & SD \\
\hline \multicolumn{4}{|c|}{ Entrepreneurial } \\
\hline 1 & I always search out new techniques, technologies for services. & 4.18 & 0.93 \\
\hline 2 & I always identify long term opportunities and threats for the company & 4.15 & 0.90 \\
\hline 3 & I put effort in pursuing new business opportunities & 4.02 & 0.76 \\
\hline \multirow[t]{2}{*}{4} & I take risks in my job & 4.11 & 0.84 \\
\hline & & 4.17 & 0.64 \\
\hline \multicolumn{4}{|c|}{ Innovation } \\
\hline 1 & At work, I try to propose my creative ideas and convince others & 4.16 & 0.77 \\
\hline 2 & At work, I seek new service techniques, methods, or techniques & 4.17 & 0.73 \\
\hline 3 & At work, I provide a suitable plan for developing new ideas & 4.05 & 0.77 \\
\hline 4 & At work, I try to secure the funding and resources needed to implement innovations & .413 & .070 \\
\hline \multirow[t]{2}{*}{5} & Overall, I consider myself a creative member of my team & 3.89 & 0.95 \\
\hline & & 4.08 & 0.43 \\
\hline \multicolumn{4}{|c|}{ Service quality } \\
\hline 1 & The company provides services as soon as possible to the customer. & 4.33 & 0.76 \\
\hline 2 & The design of service operations fit with customer requirements & 4.31 & 0.68 \\
\hline 3 & Conducting transactions quickly and adequately is very common in the company. & 4.05 & 0.93 \\
\hline \multirow[t]{2}{*}{4} & The company provides added value information on its services. & 3.99 & 0.95 \\
\hline & & 4.18 & 0.57 \\
\hline
\end{tabular}

Source: developed by the authors.

Table 5 shows that the respondents in the research has a very high attitude towards the sample and all the variables related to the customer services, and shows that the total results posit the presence of a high level of service quality which has an average mean of $4.18, S D=0.57$. The level of entrepreneurial was high, which average mean was $4.17, \mathrm{SD}=0.64$, and high level of innovation which average expect 
N. M., Aljawarneh, M., Sokiyna, A. M., Obeidat, K. A. K. Alomari, A. T., Alradaideh, Z. S., Alomari. The Role of CRM Fog Computing on Innovation and Customer Service Quality: an Empirical Study

was $4.08, \mathrm{SD}=0.43$. Testing the first hypothesis: to test the CRM fog computing on customer services for each variable in isolation, to test the first hypothesis, simple linear regression analysis was used and is illustrated in Table 6.

Table 6. Results of simple regression test of the CRM fog computing in entrepreneurial

\begin{tabular}{llllll}
\hline Independent Variable & Adjusted $\mathbf{R}^{2}$ & F-value & Coefficient & T-value & $\boldsymbol{P}$. \\
\hline CRM fog computing & 0.492 & 712.180 & 0.672 & 25.191 & 0.000
\end{tabular}

Source: developed by the authors.

Table 6 shows a positive effect of the statistical significance of CRM fog computing on entrepreneurial, and the effect level was $0.682, p>0.000$. It means that the increase in the CRM fog computing by one degree will lead to increase responding time at $67.2 \%$. It also ensures the t-statistic value 25.191 statistically significant. The adjusted $\mathrm{R}^{2}$ reached 0.492 , which indicated that CRM fog computing explains $49.2 \%$ of the changes that occur in the entrepreneurial, which implied that the variables are important in the entrepreneurial. Testing the second hypothesis, for the testing simple regression analysis was used, and Table 7 illustrates it.

Table 7. Results of simple regression test of the CRM fog computing in innovation

\begin{tabular}{llllll}
\hline Independent Variable & Adjusted R $^{2}$ & F-value & Coefficient & T-value & $\boldsymbol{P}$. \\
\hline CRM fog computing & 0.379 & 141.652 & 0.610 & 11.114 & 0.000 \\
\hline
\end{tabular}

Source: developed by the authors.

Table 7 shows a positive effect of statistically significance of CRM fog computing on the innovation, and the effect level was coefficient $=0.630, p>0.000$, meaning that the increase in the CRM fog computing by one degree will lead to increase service diversity at $61.0 \%$. It also ensures the t-statistic value 11.114 with statistically significant, which showed regression. Results also suggest that the adjusted $R^{2}$ reached 0.379 , which indicated that CRM fog computing could explain $37.9 \%$ of the changes that occur in the innovation, which implied that the variables are essential in the innovation. Testing the third hypothesis, for the testing simple regression analysis was used, and table 8 illustrates it.

Table 8. Results of simple regression test of the CRM fog computing in service quality

\begin{tabular}{lccccc}
\hline Independent Variable & Adjusted $\mathbf{R}^{2}$ & F-value & Coefficient & T-value & $\boldsymbol{P}$. \\
\hline CRM fog computing & 0.366 & 74.182 & 0.426 & 13.991 & 0.000 \\
\hline
\end{tabular}

Source: developed by the authors

Table 8 shows a positive effect of CRM fog computing on such parameter as service quality. The impact level was $0.426, p>0,000$, which means that an increase in CRM fog computing by one degree would increase customer experience by $42.6 \%$. It also included a statistically significant value of $t$ of 13.991. The service coefficient $R^{2}$ was 0.366 , indicating that CRM fog computing can account for $36.4 \%$ of service quality changes, which means that variables are essential in-service quality. The findings, based on the first question, revealed that there was a high level of CRM Fog computing. The conclusions of the second question posit that entrepreneurial, innovation and service quality levels from Jordanian telecom company employee's perspective were also high. The results of the third question showed that Jordanian telecom company and entrepreneurial, innovation and service quality were functional at $a \leq 0.05$. Iriqat and Abu Daqar (2017) proved the impact of CRM Fog computing on entrepreneurial, innovation and service quality. CRM Fog computing has a significant and positive impact on the area of entrepreneurial, innovation and service excellence because it makes this area and department's duty easier and aids better services to the customer. Investigated by the impact of CRM Fog computing on Long-term Customers' 
N. M., Aljawarneh, M., Sokiyna, A. M., Obeidat, K. A. K. Alomari, A. T., Alradaideh, Z. S., Alomari. The Role of CRM Fog Computing on Innovation and Customer Service Quality: an Empirical Study

Loyalty, they found that there is a positive relationship between long-term customers' loyalty and CRM Fog computing. Therefore, this finding agrees with the study of Iriqat and Abu Daqar (2017).

The researchers found a positive correlation between CRM Fog computing and entrepreneurial. CRM Fog computing helps to design e-commerce website of a company which includes fast email button, using which customers have the opportunity to choose the variant of contacting a company to receive a response on their queries, or they may ask or complain about transactions over the internet (Wang, 2019). There is an impact of CRM Fog computing on innovation; CRM Fog computing aids innovation due to its effects on the various aspects of innovation dished by business organisations via the internet. The use or implementation of the CRM Fog computing aids an organisation to be able to offer innovation via the internet to its customers, and this service can as well be rendered in different forms and manners. They agreed with the studies by (Agariya, 2012). There is an impact of CRM Fog computing on service quality; the CRM Fog computing positively influences service quality due to its effect on the services offered by an organisation. Customer's perceptions about the service are essential in assessing the level of the service provided. Companies need to offer excellent facilities, so they need quality services that are flexible and adjustable to customers' changing needs (Ukens, 2007). Electronic business companies use automated services to serve customers. They offer customers a chance to order, thereby increasing their loyalty (Zheng, 2019). This examination has likewise assessed the impression of the clients about service quality in private medical clinics and the degree of their fulfiment. The exploration was directed through the impact of positivism theory. Entrepreneurship is feasible, fulfilling, fulfilling and esteemed profession alternative for graduates. In acknowledgement of the enormous commitments of businesspeople, they are now and then casually alluded to as the «movers» and «shakers» in the public arena. If entrepreneurship is viewed as a wellspring of innovation, work creation and commercial development for a nation, at that point, it is critical to draw in the youthful and the informed to become businesspeople. Considering the many open doors for new pursuit creation, college understudies ought to be prepared for circumstance entrepreneurship.

Conclusions. Based on the results found, the researchers recommend building enthusiasm for creating fog CRM mist processing as a result of its job in client administrations improvement. To increase using the information provided by CRM system in decision making. To consider services quality more as it affects sales volume positively; to view customer's feedback, listen to their opinions about the services provided to enhance performance. Entrepreneurship and innovation are increasingly becoming an indispensable part of organisations at the national, regional and global levels, and are considered a powerful tool for revenue streams. Therefore, the success of the service provider often depends strictly on the high level of the relationship with entrepreneurship and innovation that determines services that influence the company's results such as increased profit (Mori et al., 2013).

Entrepreneurship uses innovation to expand the business and promote growth. Therefore, entrepreneurship and innovation are dynamic and comprehensive processes that are not limited to the initial stage of a new project. The implementations of CRM Fog computing and entrepreneurial aids the organisation's productivity because it enhances the product and senvices offered by several organisations that adopt its concept. It also aids and increases services to customers due to its easy to access nature. As well, CRM Fog computing improves the e-commerce of any organisation or community that adopts its concept and applies it in all areas. CRM Fog computing also will aid learning and teaching in any society because of the age of internet and online business and communications system. Many companies also use cloud computing because it is essential in performance growth and its effect on businesses' output.

Author Contributions: conceptualisation, N. M. A; K. A. A; methodology, N. M. A; Z. S. A.; software, A. M. A.; validation, K. A. A.; Z. S. A.; formal analysis, Z. S. A.; investigation, N. M. A; R. A.; resources, N. M. A.; data curation, N. M. A.; writing-original draft preparation, A. A.; writing-review and editing, Z. S. A; supervision, N. M. A.; project administration, N. M. A; funding acquisition, Z. S. A. 
N. M., Aljawarneh, M., Sokiyna, A. M., Obeidat, K. A. K. Alomari, A. T., Alradaideh, Z. S., Alomari. The Role of CRM Fog Computing on Innovation and Customer Service Quality: an Empirical Study

\section{References}

Abualoush, S. H., Obeidat, A. M., Tarhini, A., \& Al-Badi, A. (2018). The role of employees' empowerment as an intermediary variable between knowledge management and information systems on employees' performance. VINE Journal of Information and Knowledge Management Systems. [Google Scholar] [CrossRef]

Agariya, A. K., \& Singh, D. (2012). CRM Index development and validation in Indian banking sector. International Journal of Customer Relationship Marketing and Management (IJCRMM), 3(2), 10-32..[Google scholar] [CrossRef]

Ahmed, A., Arkian, H., Battulga, D., Fahs, A. J., Farhadi, M., Giouroukis, D. \& Tamiru, M. A. (2019). Fog Computing Applications: Taxonomy and Requirements. arXiv preprint arXiv:1907.11621. [Google Scholar]

al-Bourini, F. A., Aljawarneh, N. M., Bourini, I., Almaaitah, M. F., \& kader Alomari, K. A. (2020). Directing Strategic Decision and Perceived Faculty Performance Using PLS Analysis and Monte Carlo Simulation in Jordanian Private Universities. Journal of Talent Development and Excellence, 12(3s), 2235-2252. [Google Scholar]

Alcouffe, A., \& Kuhn, T. (2004). Schumpeterian endogenous growth theory and evolutionary economics. Journal of Evolutionary Economics, 14(2), 223-236. [Google Scholar] [CrossRef]

Aljawarneh, N. M. S., \& Atan, T. (2018). Linking Tolerance to Workplace Incivility, Service Innovative, Knowledge Hiding, and Job Search Behavior: The Mediating Role of Employee Cynicism. Negotiation and Conflict Management Research, 11(4), 298-320. [Google Scholar] [CrossRef]

Aljawarneh, N., \& Al-Omari, Z. (2018). The Role of Enterprise Resource Planning Systems ERP in Improving Customer Relationship Management CRM: An Empirical Study of Safeway Company of Jordan. International Journal of Business and Management, 13(8), 86-100. [Google Scholar] [CrossRef]

Al-Omari, Z. S., Aljawarneh, N., Davut, S., \& Salah, A. (2018). The Impact of Marketing Mix Elements on Forming Mental Images about Islamic Banks in Jordan: An Empirical Study. OFFICIAL, 12, 54. [Google Scholar]

Al-Omari, Z., Al-Omari, K., \& Aljawarneh, N. (2020). The role of empowerment in improving internal process, customer satisfaction, learning and growth. Management Science Letters, 10(4), 841-848. [Google Scholar]

Alshare, F., Aljawarneh, N., Alomari, K., Alomari, Z., Albdareen, R., AAlwagfi, A., \& Alradaideh, A. (2020). Factors influencing cellular device purchase decisions in Jordan. Management Science Letters, 10(11), 2501-2506.[Google Scholar] [CrossRef]

Antoncic, B., \& Hisrich, R. D. (2000). Intrapreneurship modeling in transition economies: A comparison of Slovenia and the United States. Journal of Developmental Entrepreneurship, 5(1), 21. [Google Scholar]

Appiah-Kubi, B., \& Doku, A. K. (2010). Towards a successful customer relationship management: A conceptual framework. African Journal of Marketing Management, 2(3), 037-043. [Google Scholar]

Atlam, H. F., Walters, R. J., \& Wills, G. B. (2018). Fog computing and the internet of things: a review. big data and cognitive computing, 2(2), 10. [Google Scholar] [CrossRef]

Bibiano, L. H., Marco-Simo, J. M., \& Pastor, J. A. (2014). An initial approach for Improving CRM systems implementation projects. In 2014 9th Iberian Conference on Information Systems and Technologies (CISTI) (pp. 1-6). IEEE. [Google Scholar] [CrossRef] Bosma, N. S., \& Levie, J. (2010). Global Entrepreneurship Monitor 2009 Executive Report.[Google Scholar] Busenitz, L. W., Gomez, C., \& Spencer, J. W. (2000). Country institutional profiles: Unlocking entrepreneurial phenomena. Academy of Management journal, 43(5), 994-1003. [Google Scholar] [CrossRef]

Bygstad, B., \& Presthus, W. (2012). Social Media as CRM? How Two Airline Companies Used Facebook during the "Ash Crisis» in 2010. Scandinavian Journal of Information Systems, 25(1), 1-22. [Google Scholar]

Coviello, N. E., \& Munro, H. J. (1995). Growing the entrepreneurial firm. European journal of marketing. [Google Scholar] [CrossRef

Ellis, J., \& Korper, S. (2001). The E-commerce Book: Building the E-empire. Academic.

Ethridge, D. (2004). Research methodology in applied economics: organising, planning, and conducting economic research (No. BOOK). Blackwell publishing.[Google Scholar]

Farquad, M. A. H., Ravi, V., \& Raju, S. B. (2012). Analytical CRM in banking and finance using SVM: a modified active learningbased rule extraction approach. International Journal of Electronic Customer Relationship Management, 6(1), 48-73. [Google Scholar] [CrossRef]

Garcia, R., \& Calantone, R. (2002). A critical look at technological innovation typology and innovativeness terminology: a literature review. Journal of Product Innovation Management: An international publication of the product development \& management association, 19(2), 110-132. [Google Scholar] [CrossRef]

Guerrero, M., Rialp, J., \& Urbano, D. (2008). The impact of desirability and feasibility on entrepreneurial intentions: A structural equation model. International Entrepreneurship and Management Journal, 4(1), 35-50. [Google Scholar] [CrossRef]

Hammad, A. N. (2019). Affecting Factors on the Timing of the Issuance of Annual Financial Reports" An Empirical Study on the sample of Iraqi Banks Listed in Iraqi Stock Exchange". Zanco Journal of Humanity Sciences, 23(4), 11-34.. [Google Scholar] [CrossRef]

Hitt, M.A., Ireland, R.D., Camp, S.M., Sexton, D.L. (2001). Guest editors' introduction to the special issue strategic entrepreneurship: entrepreneurial strategies for wealth creation. Strategic Management Journal 22, 479-491. [Google Scholar] [CrossRef]. 
N. M., Aljawarneh, M., Sokiyna, A. M., Obeidat, K. A. K. Alomari, A. T., Alradaideh, Z. S., Alomari. The Role of CRM Fog Computing on Innovation and Customer Service Quality: an Empirical Study

Hogan, S. J., \& Coote, L. V. (2014). Organisational culture, innovation, and performance: A test of Schein's model. Journal of Business Research, 67(8), 1609-1621. [Google Scholar] [CrossRef]

Hoyle, D. (2005). Automotive Quality Systems Handbook: ISO/TS 16949:2002 Edition. Elsevier. [Google Scholar]

Iriqat, R. A., \& Daqar, A. (2017). The Role of Customer Relationship Management on Enhancing the Customers' Satisfaction in the Banks in Palestine. Modern Applied Science, 11(12). [Google Scholar] [CrossRef] Irtaimeh, H. J., Obeidat, A. M., Abualloush, S. H., \& Khaddam, A. A. (2016). Impact of Business Intelligence on Technical Creativity: A Case Study on AlHekma Pharmaceutical Company. European Scientific Journal, 12(28), 502-519. [Google Scholar] [CrossRef]

Jiang, H., \& Zhang, Y. (2016). An investigation of service quality, customer satisfaction and loyalty in China's airline market. Journal of air transport management, 57, 80-88. [Google Scholar] [CrossRef]

Khairo Al-Da'abseh, T., Saleh Aljawarneh, N. M., \& Mustafa Shwiyat, Z. (2018). Marketing Mix Startegies and Its Impact on Organisational Performance Efficiency in the Jordanian Company for Investment and Supply-Safeway: An Empirical Study. Invention Journal of Research Technology in Engineering \& Management, 2(2), 14-23. [Google Scholar] [CrossRef]

Khaligh, A. A., Miremadi, A., \& Aminilari, M. (2012). The impact of eCRM on loyalty and retention of customers in Iranian telecommunication sector. International Journal of Business and Management, 7(2), 150. [Goolge Scholar] [CrossRef] Kheng, L. L., Mahamad, O., \& Ramayah, T. (2010). The impact of service quality on customer loyalty: A study of banks in Penang, Malaysia. International journal of marketing studies, 2(2), 57. [Google Scholar] [CrossRef]

Khlif, H., \& Jallouli, R. (2014). The success factors of CRM systems: An explanatory analysis. Journal of Global Business \& Technology, 10(2), 25-42. [Google Scholar]

Kiran, K., \& Diljit, S. (2017). Antecedents of customer loyalty: Does service quality suffice? Malaysian Journal of Library \& Information Science, 16(2), 95-113. [Google Scholar]

Klepper, S. (2015). Experimental capitalism: The nanoeconomics of American high-tech industries. Princeton University Press. [Google Scholar]

Knight, G. A., \& Cavusgil, S. T. (1996). The born global firm: A challenge to traditional internationalisation theory. Advances in international marketing, 8(1), 11-26. [Google Scholar]

Kumar, V., \& Reinartz, W. (2016). Creating enduring customer value. Journal of Marketing, 80(6), 36-68. [Google Scholar] [CrossRef]

Kurbel, K. E. (2013). Enterprise Resource Planning and Supply Chain Management. New York: Springer. [Google Scholar]

Ladhari, R. (2008). Alternative Measure of Service Quality: A Review. Journal of Managing Service Quality, 18(1), 65-86.

[CrossRef] [CrossRef]

Mahafzah, A. G., Aljawarneh, N. M., Alomari, K. A. K., Altahat, S., \& Alomari, Z. S. (2020). Impact of customer relationship management on food and beverage service quality: The mediating role of employees satisfaction. Humanities \& Social Sciences Reviews, 8(2), 222-230. [Google Scholar] [CrossRef]

Malkawi, N. M., Baniata, M. I., \& Obeidat, A. M. (2017). The Impact of E-Government Applications on Decision-Making Effectiveness: Case Study at Jordanian Ministry of Interior-Jordan. International Review of Management and Business Research, 6(1), 172. [Google Scholar]

Mang'unyi, E. E., Khabala, O. T., \& Govender, K. K. (2017). The relationship between e-CRM and customer loyalty: A Kenyan Commercial Bank case study. Banks \& bank systems, 12(2), 106-115[Google Scholar] [CrossRef]

Mitchell, V. W. (1990) Defining and measuring the quality of customer service. Marketing Intelligence \& Planning, 8(6), 11-17. [Google Scholar] [CrossRef]

Mohammed, A. A., \& bin Rashid, B. (2012). Customer Relationship Management (CRM) in Hotel Industry: A framework proposal on the relationship among CRM dimensions, Marketing Capabilities, and Hotel performance. International Review of Management and Marketing, 2(4), 220-230. [Google Scholar]

Moorthi, D. (2020) e-CRM an overview. Journal of Interdisciplinary Cycle Research, 12(3), 795-801. Retrieved from http://www.jicriournal.com/gallery/88-jicr-march-2516.pdf

Mori, D., Ranawaka, U., Yamada, K., Rajindrajith, S., Miya, K., Perera, H. K. K., ... \& Nishizono, A. (2013). Human bocavirus in patients with encephalitis, Sri Lanka, 2009-2010. Emerging infectious diseases, 19(11), 1859. [Google Scholar] [CrossRef]

Parasuraman, A., Zeithaml, V. A., \& Berry, L. L. (1985). A conceptual model of service quality and its implications for future research. Journal of marketing, 49(4), 41-50.[Goolge Scholar]

Portela, M. C. \& Thanassoulis, E. (2007). Developing a decomposable measure of profit efficiency using DEA. Journal of the Operational Research Society, 58(4), 481-490. [Google Scholar] [CrossRef]

Sekaran, U., \& Bougie, R. (2015). Research Methods for Business: A Skill-Building Approach. John Wiley \& Sons. [Google Scholar]

Soliman, H. S. (2011). Customer Relationship Management and Its Relationship to the Marketing Performance. International Journal of Business and Social Science, 2(10), 166-182. [Google Scholar]

Spathis, C., Petridou, E., \& Glaveli, N. (2004). Managing service quality in banks: customers gender effects. Managing Service Quality: An International Journal. [Google Scholar] [CrossRef]

Su, X., Liu, S., Zhang, S., \& Liu, L. (2020). To Be Happy: A Case Study of Entrepreneurial Motivation and Entrepreneurial Process from the Perspective of Positive Psychology. Sustainability, 12(2), 584. [Google Scholar] [CrossRef] 
N. M., Aljawarneh, M., Sokiyna, A. M., Obeidat, K. A. K. Alomari, A. T., Alradaideh, Z. S., Alomari. The Role of CRM Fog Computing on Innovation and Customer Service Quality: an Empirical Study

Sulistyo, H. (2016). Innovation capability of SMEs through entrepreneurship, marketing capability, relational capital and empowerment. Asia Pacific Management Review, 21(4), 196-203 [Google Scholar] [CrossRef]

Sulistyo, H., \& Ayuni, S. (2020). Competitive advantages of SMEs: The roles of innovation capability, entrepreneurial orientation, and social capital. Contaduría y Administracion, 65(1), 156. [Google Scholar] [CrossRef]

Tao, F., Zhang, L., Venkatesh, V. C., Luo, Y., \& Cheng, Y. (2011). Cloud manufacturing: a computing and service-oriented manufacturing model. Proceedings of the Institution of Mechanical Engineers, Part B: Journal of Engineering Manufacture, 225(10), 1969-1976. [Google Scholar] [CrossRef]

Tian, X., \& Wang, T. Y. (2014). Tolerance for failure and corporate innovation. The Review of Financial Studies, 27(1), 211-255. [Google Scholar] [CrossRef]

Ukens, L. L. (2007). 101 ways to improve customer service: training, tools, tips, and techniques. John Wiley \& Sons. [Google

Scholar]

Vikkraman, P \& Duraikannan, A (2015). Linkage Between Customer Relationship Management and Its Consequences in Life Insurance Industry: A Customer Centric Analysis. International Journal of Applied Engineering 10(8), 20715-20724.

Wang, J., Zheng, P., Lv, Y., Bao, J., \& Zhang, J. (2019). Fog-IBDIS: Industrial big data integration and sharing with fog computing for manufacturing systems. Engineering, 5(4), 662-670. [Google Scholar] [CrossRef]

Надер Мохаммед Аляварне,

Університет Джадара, Йорданія

Мунсиф Сокійна,

Ph.D., Кіпрський міжнародний університет, Кinp

Абдалла Мішаел Обейдат,

Університет Джадара, Йорданія

Халед Абдель кадер Аломарі

Університет Джадара, Йорданія

Ахмад Таусфіг Альрадайде,

Університет Джадара, Йорданія

Зіяд Салех Аломарі

Університет Джадара, Йорданія

Вплив туманних обчислень CRM на інновації та якість обслуговування клієнтів: емпіричне дослідження

У статті проаналізовано розвиток CRM-модель туманних обчислень, інновацій, підприємницького потенціалу та якості обслуговування як рушійних сил розвитку економіки та створення нових робочих місць. Головною метою статті $\epsilon$ дослідження впливу CRM-моделі туманних обчислень на підприємницький потенціал, рівень інноваційності та якості обслуговування споживачів. Детерміновану вибірку даних сформовано на основі результатів анкетування 325 респондентів - працівників телекомунікаційної компанії в Йорданії. Для аналізу панельних даних авторами використано множинні лінійні регресії та одно факторний дисперсійний аналіз ANOVA (One-Way ANOVA). Bcтановлено, що CRMмодель прогнозування туманних обчислень має статистично значущий вплив на розвиток підприємницького потенціалу, рівень інноваційності та якості обслуговування споживачів. У статті запропоновано рекомендації щодо застосування CRM-моделі туманних обчислень для удосконалення процесу комунікації зі споживачами; розширення інформаційної бази у проиесі прийняття рішень; детального аналізу факторів впливу на рівень якості обслуговування для зростання об'єму продажів компанії; урахування відгуків та думок споживачів про надані послуги з метою покращення конкурентоспроможності компанії. Авторами зазначено, що підприємницький потенціал та інноваційність є основою розвитку компанії на національному, регіональному та глобальному рівнях, а також потужним інструментом для залучення додаткових інвестиційних ресурсів. Відмічено, що підприємницький потенціал та інноваційність є динамічними та комплексними процесами, які супроводжують кожну стадію життєвого циклу компанії. При иьому високий рівень інноваційності у підприємницькій діяльності розширює сфрери діяльності компанії. У статті зазначено, що впровадження CRM-моделі туманних обчислень та підвищення підприємницького потенціалу сприяє зостанню обсягів онлайн-продажів та рівню прибутковості компанії.

Ключові слова: CRM-модель, Fog computing, підприємництво, інноваційність, якість обслуговування, рівень задоволення клієнта.

Manuscript received: 06.01.2020

(C) The author(s) 2020. This article is published with open access at Sumy State University 